\title{
OBJECTIFIED WOMEN AND FETISHIZED OBJECTS
}

\author{
Paula Keller
}

FAMILIAR CRITIQUE of advertisements from the clothing company Amer-
ican Apparel is that they portray women in objectifying ways. Take this
example: in 2012 the brand printed an advertisement of a young woman in a bodysuit, legs apart, looking lasciviously into the camera, with the caption "Now Open," leaving ambiguous exactly what is open now. ${ }^{1}$ This is clearly objectification-but why? The woman is presented as object-like, as inanimate; she is compared to a store. This explanation fits a widespread idea associated with objectification: treating people as if they were objects.

But there is a second sense of objectification: the woman in the American Apparel ad is presented in this object-like way because it fits straight-male sexual desires. Those shopping at and those creating American Apparel want to see her naked, open legs; they derive sexual pleasure from those legs. So American Apparel advertisements make her that way in their pictures. This is a second sense of objectification: the content of sexual desire is projected onto women; one then thinks that women are the way one sexually desires them to be. What was formerly subjective desire becomes belief about objective reality. We can call this an objectification of desires. Projection is an idea familiar from other areas of philosophy: we see colors in the world because we project them onto objects, some have argued in the philosophy of mind. ${ }^{2}$ We discern moral value in the world because we project it onto the world, J.L. Mackie has argued in ethics. ${ }^{3}$ Taking this idea to feminist philosophy, projection in American Apparel adver-

1 The brand has since gone bankrupt and in 2017 reopened under a new image. It now advertises with inclusivity in skin color and body shape: "Introducing our first-ever inclusive nude collection: a celebration of authentic, diverse representation. NUDES encompasses a broad spectrum of skin colors, with sexy premium essentials in 9 shades of nude." American Apparel, accessed January 10, 2021, https://americanapparel.com/women/nudes.

2 Most notably, Locke, An Essay Concerning Human Understanding, bk. II, ch. 8, secs. 9-10.

3 Mackie, Ethics, ch. 1. 
tisements is about how sexual desires shape how American Apparel customers and creators think about and represent women-here projection is a mechanism from desire to belief.

So we get two related ideas of objectification: treating as objects and forming projective beliefs. Catharine MacKinnon captures both in saying that

like the value of a commodity, women's sexual desirability is fetishized: it is made to appear a quality of the object itself ... inherent, independent of the social relation that created it. ${ }^{4}$

Here is how this captures the two ideas above. First, MacKinnon speaks of women as objects - the first idea above of treating as objects. I will call this the moral idea. Second, MacKinnon specifies that the "social relation" of one sexually desiring women is projected onto the objects, women. This is the second, epistemic idea. MacKinnon also adds a third dimension: sexual objectification typically happens to women. It is not a personal but a political phenomenon.

A liberal camp around Martha Nussbaum is interested mostly in the moral idea; a radical, Marxist camp around Catharine MacKinnon and Sally Haslanger is concerned with the political idea; and a third group of feminists like Rae Langton and also Haslanger note the epistemic idea. ${ }^{5}$ How do these three senses fit together? For Lina Papadaki they are rivals. For Kathleen Stock they are entirely different projects: Nussbaum's account is said to capture the ordinary, folk usage of the term "objectification." Epistemic and political accounts are said to describe a problematic phenomenon in the world that, for classificatory purposes, is labeled "objectification."

I disagree with both Stock's and Papadaki's outline of the field. Instead, I suggest that MacKinnon's quote above can reveal a relation between the three senses: commodity fetishism can function as a model for how to make sense of their relation. This Marxist concept also comprises a moral, political, and epistemic sense and so allows us to read these three senses as pointing out three aspects and three wrongs in one phenomenon-not three different phenomena nor three different claims of what is essential to one phenomenon. My aim is not to defend particularities of each idea of objectification —instead I first collect them to then focus on their connection. My point is not only that all three senses are aspects of one phenomenon, but rather that moral, political, and epistemic fac-

4 MacKinnon, Toward a Feminist Theory of the State, 123; see also MacKinnon, Feminism Unmodified.

5 See Haslanger, "On Being Objective and Being Objectified," 241-66.

6 Papadaki, "What Is Objectification?"; Stock, "Sexual Objectification." 
tors interact-without any one of them, we cannot fully explain the widespread existence of the other two. This again is analogous to commodity fetishism.

So what is this talk about commodities and fetishizing? MacKinnon takes it from Marx. Commodity fetishism, in Marx's Capital, describes roughly the idea that on the market a product seems to have its value inherently, rather than due to the social relations of production and exchange that really give it value.

Comparing commodity fetishism to sexual objectification is novel because MacKinnon only tentatively suggests this analogy at various places throughout Feminism Unmodified and Toward a Feminist Theory of the State. We cannot, however, there find a systematic argument for the analogy-MacKinnon leaves work to be done. But what is even more interesting is that nobody has taken up this task: that these two phenomena should be similar is not only relevant for a hybrid account of objectification, but helpful for understanding how self-sustaining social systems work. Sexual objectification, or so I argue, comprises moral, political, and epistemic mechanisms to uphold a patriarchal structure, and the same is true for commodity fetishism and capitalism.

My argument will also show that there is more to sexual objectification than merely treating a person as an object. This is relevant especially since the moral sense- the much more widely accepted sense-focuses only on this definition. We will see that this moral sense is an oversimplification that leaves questions about the functioning and consequences of sexual objectification unanswered. My project further fits into a wider debate between Marxists and feminists about which of the two frameworks to apply or how to reconcile them. If my argument works, it suggests a general aptness to use Marxist concepts for feminist projects. "Fetishism" might be one example; "alienation" and "ideology" are others.

So what is the analogy between commodity fetishism and sexual objectification? First, sexual objectification reinforces patriarchal social structures. ${ }^{9}$ Second, male sexual desire generates a belief about women: the woman in the advertisement is represented as object-like because American Apparel and its customers

7 Although Nussbaum's moral account is already twenty-five years old, it is still a standard in debates on objectification. Here is just a small selection of feminist philosophers working with this account: Papadaki, "Sexual Objectification"; Saul, "On Treating Things as People"; Marino, "The Ethics of Sexual Objectification"; and Langton, Sexual Solipsism.

8 For "alienation" see Bartky, Femininity and Domination; for "ideology" see Haslanger, "But Mom, Crop-Tops Are Cute!”

9 Following MacKinnon, sexual objectification is what solely defines gender and gender inequality. I am not committed to this strong thesis and will rather follow Haslanger's assumption of a plurality of factors that constructs gender inequality in "On Being Objective and Being Objectified." For more on this and the indebtedness of my account to Haslanger's see section 3 below. 
want her to be. Those groups think that the portrayed woman really has these object-like features inherently: they do not think that the origin of this thought is their own sexual desire. ${ }^{10}$ Third, the woman in the picture really looks object-like: the picture is evidence for the belief that she is object-like. Similarly, commodity fetishism reinforces capitalist social structures, involves agents forming the belief that commodities have value inherently, and produces evidence supporting this belief. So sexual objectification and commodity fetishism are analogous because both involve the following features:

1. Social structure

2. False belief about inherent property

3. Evidence production

That both phenomena reinforce (1) a social structure makes them alike in their function. This paves the ground for a further comparison regarding moral, political, and epistemic aspects: what at first sight looks overly epistemic — speaking of (2) belief and (3) evidence-will turn out to also entail moral and political senses. This analogy allows us to see that an adequate account of sexual objectification must be a hybrid account recognizing moral, political, and epistemic aspects and wrongs involved in the phenomenon.

To show this I first present the moral, political, and epistemic senses of sexual objectification and make some suggestions regarding their possible relationships (in section 1). In section 2, I outline what commodity fetishism is. Sections 3 through 5 explain the analogy with features $1-3$ above.

\section{THEORIES OF OBJECTIFICATION}

\subsection{Moral Objectification}

The moral sense of sexual objectification best fits public discourse about objectification. Nussbaum gives the canonical account: "In all cases of objectification what is at issue is a question of treating one thing as another: one is treating as an object what is really not an object, what is, in fact, a human being." ${ }^{11}$ This

10 I follow MacKinnon (quoted above) in her use of "inherently" to mean that a particular property comes with the object. The relevant contrast is that a property is endowed onto the object by a social relation. Consider these examples: wine has the inherent property of being a liquid (at room temperature), while-for Catholics-it also has the property of being holy in certain contexts when it signifies Jesus's blood. This latter property is due to a social relation-it is not inherent.

11 Nussbaum, "Objectification," 256-57. This basic idea of objectification is derived from Kant, Lectures on Ethics. 
need not mean that one is treating another as if they were an actual object, say a pen, a painting, or a zucchini. It means rather that aspects of one's behavior or one's attitude toward another person resemble behavior one might also display toward a pen one uses for writing, a painting one marvels at, or a zucchini one buys at the supermarket.

But what makes objectification sexual objectification, what exactly does it mean to treat as an "object," and how is this morally dodgy? Nussbaum's initial definition is in need of specification.

First, treating a person as an object might not always be morally objectionable. Here is Nussbaum's example: "If I am lying around with my lover on the bed, and use his stomach as a pillow, there seems to be nothing at all baneful about this, provided that I do so with his consent" and in an environment of mutual equality and respect. ${ }^{12}$ Some pleasurable aspects of sexual life, as Nussbaum further notes, might even depend on objectification: gazing at one's partner like one gazes at a statue or using one's partner for one's own sexual pleasure are to some extent enjoyable features of our sexual life. For something to be morally objectionable objectification, Nussbaum suggests that we need to add that objectification is the primary treatment: if I treat my lover primarily as a pillow, that is morally objectionable. ${ }^{13}$ In this case, as opposed to the one-off case from before, the lover's general humanity is either actively denied or passively disregarded. Following Papadaki's explication of Nussbaum, it is this denial/disregard that makes objectification morally objectionable. ${ }^{14}$ While Nussbaum is not too explicit on what exactly distinguishes morally permissible from impermissible objectification, perhaps the rough picture is clear enough: both kinds exist and pervasiveness and context determine moral permissibility.

Second, there are several senses of treating someone as an "object." Nussbaum lists seven to which Langton adds three further ones; I highlight three of Nussbaum's senses and merely gesture toward the others.

1. Instrumentality involves using someone as a tool for one's own ends. Someone masturbating to the American Apparel advertisement "Now Open" uses the picture of the girl as an instrument.

Nussbaum, “Objectification,” 265.

Nussbaum, “Objectification.” How consent features here is unclear: Does it make even primary objectification acceptable? Is all nonconsensual objectification morally bad or can there be mild cases of morally permissible objectification not in need of consent? Nussbaum only suggests that both primary treatment and consent combined with equality and respect are relevant for determining objectification's moral status (“Objectification,” 265).

Papadaki, "What Is Objectification?” 24-25. 
The remaining six features (and Langton's three) have to do with a sexual desire that one's partner be a passive object one can do things to.

2. Objects of this kind lack autonomy-Nussbaum's second feature. James Bond movies illustrate this well:

James Bond: In the 2015 film Spectre, Q introduces Bond to a new car: "Magnificent, isn't she?... Beautiful tricks up her sleeve." Cars are female! Across the Bond movies, car scenes are paired with Bond making out with Bond girls. The viewer cannot help but notice that Bond girls and cars are both female and both things Bond plays with. Cars are not autonomous agents, so neither are Bond girls. ${ }^{15}$

3. Objects are inert and Langton adds that they do not speak and are mere bodies or appearances. ${ }^{16}$ This fits the following ad campaign where beauty, not activity, matters:

Helmet Campaign: The German government in March 2019 made a campaign to motivate cyclists to wear helmets. Their slogan "Looks like shit. But saves my life" was paired with images of nearly naked helmet-wearing women (and some men) posing in beds, not active on bikes. ${ }^{17}$

This focus on inertness makes clear that the moral wrong involved in objectification is not that one pays exclusive attention to material bodies rather than mental persons. Accusations that feminists working on objectification perpetuate a mind-body hierarchy are therefore mistaken. ${ }^{18}$ In a world where our materiality as well as our interdependence on one another is often disregarded, explicit at-

15 James Bond objectifies despite being just a fiction: fictions objectify fictional women, cause objectification of nonfictional women, and constitute objectification of nonfictional women (see, e.g., MacKinnon, Feminism Unmodified, ch. 14; Langton, Sexual Solipsism, ch. 1). A different description of the James Bond example would be that the car is partially upgraded to person status, while Bond girls are partially downgraded so that they meet in the middle. Saul discusses a similar case using the example of vibrators in "On Treating Things as People."

16 Langton, Sexual Solipsism, 228-29. One might here object that treating one as a body need not be bad. In fact, deeming it bad disregards our embodied lives and wrongly privileges the mental. But Langton can be defended by pointing out that objectification, according to her, reduces us to "body parts" or appearances like "fine paintings and antiques." The relevant contrast is not between the mental and the bodily, but between living and dead/disassembled/two-dimensional. Agence France-Presse, "German Ministry under Fire over 'Sexist' Bike Safety Ad."

For example by Cahill, Overcoming Objectification. Once this accusation falls, there seems to me to no longer be a need to replace objectification with a different concept, such as Cahill's derivation. 
tention to our embodied, not entirely autonomous nature is not objectionable. But this attention is not subject to criticism by feminists working on objectification. What characterizes material feminists' emphasis on one's body is that they thereby mean an "active, viable and autonomous body"- as opposed to an enslaved, used, or forced body." ${ }^{19}$ This body deserves recognition. It is precisely these characteristics of bodies as alive, autonomous, with subjective feelings and emotions that objectification harms or denies-and that feminists working on the topic object to. Critiques of objectification do not rank minds over bodies; they rank living, autonomous human beings (with both mind and body) over innate objects or nonautonomous instruments. Materiality and embodiment are hotly debated within feminism, and my quick remarks on the matter do not settle these debates. I, however, hope to have shown how one might think of the two parties presented as allies rather than rivals. The idea of the object-like inferior body (be it as a degradation of women or as general conception of the body) is the common enemy of feminists working on objectification and those working on materiality and embodiment.

Third, we can distinguish sexual from other objectification: the former is objectification in a "sexual context" for Nussbaum. ${ }^{20}$ A master owning a slave or a capitalist employing a worker are examples of nonsexual objectification. ${ }^{21}$ American Apparel, James Bond, and Helmet Campaign are all examples of sexual objectification, as is the following video advertisement:

Miller Lite: Two women get into an argument about why one should drink the beer Miller Lite. The argument gets physical: they first fight each other in a water fountain, then in a mud pit, pulling off each other's clothes - the pinnacle of the scene is them making out. It becomes clear that the scene springs from the fantasy of two men in a bar, imagining the perfect beer commercial. ${ }^{22}$

In this ad the women are instruments for the men's sexual pleasure. This is objec-

19 See Grosz, Volatile Bodies, 9. It is important to note that the relevant contrast is not between autonomous on the one hand and socially dependent on the other. On this picture autonomy would be, as Cahill rightly notes, "not only a fantasy, but a nightmare" for us socially dependent beings; see Cahill, Overcoming Objectification, 23. For classic work that emphasizes the importance of this living, relatively autonomous, yet still socially dependent body and critiques a cultural degradation of this body as opposed to the pure, rational mind, see, for example, Young, On Female Body Experience; Bordo, Unbearable Weight; and Weiss, Body Images.

20 Nussbaum, "Objectification," 251.

21 Nussbaum, “Objectification," 262-65.

22 Cahill, Overcoming Objectification, 42-47. 
tification in a sexual context, not just objectification simpliciter. Miller Lite also shows how sexual objectification might reinforce patriarchal structures-in this case by conveying norms of ideal behavior for women. This introduces a second, political sense of objectification, which I turn to next.

Putting together what we have, let us work with the following moral sense of sexual objectification:

$X$ constitutes (moral) sexual objectification iff $X$ is a treatment in which a person $a$, in a sexual context, treats another person $b$ as if $b$ were primarily an object (e.g., an instrument, lacking autonomy or inert).

\subsection{Political Objectification}

Miller Lite reinforces patriarchal structures. This reinforcement is powerful because, following MacKinnon, sexual objectification is itself structural: Miller Lite is just one part of an "elaborate ... system" with frequent instances. ${ }^{23}$ Sexual objectification becomes an important factor in our social world. The elaborate system produces two classes and a hierarchy between them: a class of objectified and of objectifiers. For MacKinnon, objectification not only disproportionately affects one gender-women-it defines what it means to be of different genders. The class of objectified are "women" and the objectifying class are "men": "the sex difference and the dominance-submission dynamic define each other." ${ }^{24}$ "Women are the things and men are the self." 25

This shows that structural objectification, analogous to moral objectification, also involves a degradation to thing-hood. But, following Haslanger, this account lays particular emphasis on women becoming instruments. ${ }^{26}$ In this respect it resembles particularly closely Nussbaum's first sense of objectification. While Nussbaum's account was vague about the specifics of sexual objectification-objectification in a sexual context - the political account is more concrete, giving two ways in which objectification is sexual: women become instruments for sexual pleasure specifically, rather than mere instruments in a sexual context, and the thereby affected gender hierarchy is itself eroticized. So women are not merely tools for men's sexual pleasure; men also derive pleasure from women being the subordinate class. ${ }^{27}$

MacKinnon, Toward a Feminist Theory of the State, 141.

MacKinnon, Feminism Unmodified, 50, and 40-42.

MacKinnon, Feminism Unmodified, 123.

See Haslanger, "On Being Objective and Being Objectified," 64-65.

MacKinnon, Feminism Unmodified, 54; Stock also identifies these two factors for sexual objectification ("Sexual Objectification"). 
MacKinnon's political sense does not mean that all men (or only men) objectify women, rather sexual objectification is something "most men adhere to ... nonconsciously ... [because] it is rational for them." ${ }^{28}$ For MacKinnon, men play the central (but not exclusive) role in sexual objectification. And sexual objectification works: it creates complying, self-objectifying, and inferior female subjects, as Haslanger notes. ${ }^{29}$

On this picture, sexual objectification is objectionable not only for the moral reason that it denies or disrespects a person's humanity, but because it reinforces the "subjection of women." 30 This is true for any sexually objectifying acts, not just for those that are primary or exclusive. This political harm further means that while not all women might directly experience sexual objectification in the form of degrading treatment by men (although it is likely most will), sexual objectification affects them all, in virtue of their membership in the class of women. Sexual objectification makes all women inferior.

Putting this account together, we get the following:

$X$ constitutes (political) sexual objectification iff $X$ is a system of relations between agents such that women socially count as instruments for sexual pleasure while men count as selves, and this gender hierarchy is eroticized.

But moral and political senses leave questions unanswered: Why exactly is sexual objectification of women such a pervasive social phenomenon? If sexual objectification is either morally or politically bad and at least some or most of the objectifiers are responsible moral and political agents, would we not expect them to reduce or attempt to reduce their objectionable behavior? So far, we cannot really make sense of the social reality of sexual objectification: How are the American Apparel example and Helmet Campaign, James Bond, and Miller Lite possible?

\subsection{Epistemic Objectification}

Langton, MacKinnon, and Haslanger give answers to these questions by highlighting an epistemic sense of sexual objectification. The epistemic sense involves

28 MacKinnon, Feminism Unmodified, 114.

29 Haslanger, "On Being Objective and Being Objectified," 61.

30 MacKinnon, Feminism Unmodified, 124. This point is contested: Papadaki ("What Is Objectification?") and Stock ("Sexual Objectification") understand the objectionable nature of MacKinnon-style objectification to primarily have to do with treating someone as a means to an end and therefore in some way violating their humanity. While I do not deny that this might add to objectification's objectionable nature, I maintain that MacKinnon's focus is on badness due to gender hierarchy. 
two ideas: projective beliefs about women and the production of evidence that women are as one believes them to be. ${ }^{31}$ What was formerly subjective desire becomes (belief about) objective reality-it is objectified. I briefly outline the epistemic sense focusing on the first idea. I spend more time on the second idea in section 5 .

Projection in the context of sexual objectification is belief formation about some person due to sexual desire. Here are some familiar examples of such beliefs that a sexual objectifier might form: women are dressed like this so that I can enjoy looking; they like me hitting on them; they sexually desire exactly what I desire; it is impossible for women not to find me attractive, etc. Projection involves, following Langton, the "capacity to generate a belief" that a particular world state is true without making use of external evidence. ${ }^{32}$ If one projects "they like me hitting on them" onto women, that means one generates this belief without external evidence (e.g., from the observation of women). Projection in the case of sexual objectification means "viewing certain individuals through the lens of one's [sexual] desire."33

Projective belief formation is not ordinary belief formation. Ordinarily, "beliefs aim to fit the world." ${ }^{4}$ (Remember Anscombe's famous shopping cart detective. $)^{35}$ James Bond's belief about what sort of organization Spectre is aims to fit (and is created by observation of) the world with Spectre in it. Projective beliefs do the opposite: they are not created by observation with the aim to fit the world. Rather they are generated, in our case, from a particular sexual desire. The Miller Lite example makes this mechanism explicit: we see two women drinking beer, then they start making out. What we at first mistake for a depiction of reality turns out to be a product of male imagination guided by sexual desire. The lines are blurred between sexual fantasy and reality: Do the men in the commercial really know the difference between these two? Are they fully aware that what they imagine women to be like is not what they are actually like? Or is the scenario's sexual appeal at least partly due to the fact that the imagined scene is not entirely unlike their (and the heterosexual, male target audience's) perceived reality?

Cahill's competitor-concept "derivatization" also stresses projection: derivatization amounts to de-subjectifying another. One way of taking away subjectivity is to project properties or characteristics onto them regardless of whether they have those or not: "framing or constructing the feminine in terms of the masculine" (Cahill, Overcoming Objectification, 50).

Langton, Sexual Solipsism, 247.

Haslanger, "On Being Objective and Being Objectified," 60.

Anscombe, Intention, 56. 
The person who forms the belief via projection will be unaware of its origin in sexual desire. James Bond believes that a Bond girl is primarily a beautiful object to such an extent that he is surprised and unprepared when a Bond girl in Goldeneye attacks him-objects do not have autonomy or subjectivity, so they cannot attack. If Bond found out that projection was the way in which he acquired his belief about Bond girls as objects, he would be suspicious of that belief. Keeping his belief would mean risking his life, as the example showed, and it would make him a bad MI6 agent. If he holds this projective belief and if he is (let us assume) a good MI6 agent, he cannot be aware of the projective nature of his belief. Langton asserts accordingly: "projection must make its origins invisible if it is to be belief at all." 36

Aside from projection, the epistemic sense contains a second idea: Bond will treat women according to his projective beliefs about them. If others do so too, women will be made objects (at least socially). This comes back full circle to Bond's beliefs: Bond observes women counting as objects in the social world; he uses that as evidence for his beliefs about women. I say more about evidence in section 5 as it becomes relevant for my comparison to commodity fetishism.

For now, we can combine an epistemic sense:

$X$ constitutes (epistemic) sexual objectification iff (1) $X$ is a belief-forming mechanism in which an agent $a$ forms a belief that some other person $b$ has some inherent properties due to $a$ 's sexual desires and $a$ is unaware of this causal relation, and (2) $b$ might be treated according to this belief such that evidence for $a$ 's belief is produced.

\subsection{Moral, Political, and Epistemic Senses Combined?}

How do these three accounts of sexual objectification fit together? In one case sexual objectification is an action, in the other it is a system, in the third it is a particular kind of belief. These seem to be entirely different things. Is it still the case that all three accounts describe the same phenomenon, or do they rather denote completely different aspects of our social lives? My claim is that there is a core phenomenon of sexual objectification in which all three senses show up. A comprehensive account of sexual objectification must therefore be multifaceted. My comparison with commodity fetishism will show how these facets can be combined. But let us start by understanding the differences and similarities among the three accounts.

First, we often act due to our beliefs; so, in a context of political objectification, epistemic objectification might (paired with an intention) cause moral 
objectification. If I believe women to be objects, I will treat women as if they were objects. Here are more concrete examples: if one believes that women are there to please men, one (as a man) will treat them as instruments for one's pleasure (Nussbaum's feature). If one believes that it does not matter whether one's girlfriend is a scientist or a philosopher as long as she is pretty, one will treat her as interchangeable with other pretty women (also one of Nussbaum's seven features). The treatment, which the moral sense talks about, can therefore be a consequence of epistemic projective belief. Frequent such treatment further serves to build up the eroticized gender hierarchy the political sense refers to.

Second, moral and political senses of sexual objectification can provide evidence for the previously unjustified belief formed according to the epistemic sense. If Bond and the like go around treating women as objects, their treatment can be evidence for others that women are object-like; this makes an objectifying belief justified-I come back to this in section 5 .

Perhaps the political sense could be understood as a specification of the moral sense: it adds a systemic context to the moral sense and determines who the objectifying agents are-men. But this picture is inaccurate: the political sense not merely adds context, its main focus is on this context. Compared to the moral sense, the political sense therefore shifts the attention to a different phenomenon: first, we are interested in actions, then we are interested in social structure. Surely, the first somehow enacts the second: a society with political objectification must to some extent also feature moral objectification. But the political sense is not simply a subclass of the moral sense.

Looking at the relations between all three senses of objectification, we can see that there are often no tight connections. First, moral objectification can exist without political objectification-take Nussbaum's politically innocent pillow example and (to make it morally objectionable) imagine this were Nussbaum's primary treatment of her lover. Because it goes against the dominant direction of men objectifying women, it does not fit the political sense.

Objectification in the epistemic sense need not be objectification in the moral and political sense. Take this example:

Ann's Perfect Boyfriend: Ann sexually desires boyfriends who are kind and loving. But Joe, her boyfriend, is not like that. Ann desires Joe to be loving and kind to such an extent that she starts believing that Joe is loving and kind and treats him accordingly. ${ }^{37}$

This is an example of the epistemic sense: Ann projects a property onto Joe that Ann sexually desires Joe to have. But it is also a property that Joe does not have.

37 James describes a similar process in The Will to Believe, 23. 
Ann is unaware that her belief was formed via projection. Yet this example has nothing to do with the moral sense of sexual objectification: Ann at no point treats (or could from her projective belief about Joe come to treat) Joe as an object in a morally objectionable way, nor does she thereby participate in upholding an elaborate system of the objectification of women. So some cases of projective objectification are morally and politically innocent.

Conversely, some cases of moral and political objectification are not projective-they are epistemically innocent:

Sadistic Rape: This is rape "where non-consent is actively sought, rather than disregarded or ignored. In this sort of case, it's not that he doesn't listen to her saying 'no'- he wants her to say 'no."'38 The rapist wants to violate and degrade his victim to the status of an object. He does not believe that she already is an object-he makes her one deliberately.

While Sadistic Rape is morally appalling sexual objectification and partakes in a system of women's objectification, it is not an example of epistemic projective belief formation: the rapist treats his victim as an object but not because he desires and therefore believes that she is one. Instead, he knows full well that she is a person and that he violates her; this violation is what he sexually desires.

I showed that moral, political, and epistemic senses relate to one another like overlapping circles in a Venn diagram. But which sense describes what sexual objectification really is? All do! To see this I turn to the comparison with commodity fetishism.

\section{COMMODITY FETISHISM AND THREE KINDS OF VALUE}

I first ask what exactly it means to speak of a fetish in this case. Then, following Marx, I distinguish three kinds of value. This distinction allows us to understand why, for Marx, commodities are fetishized. Note that it is not my aim to convince you of the existence of commodity fetishism. Even if Marx was wrong about it, the result that sexual objectification works like Marx thought commodity fetishism worked will still be interesting: it will show how a social phenomenon can have moral, political, and epistemic aspects simultaneously. But for now let us assume that commodity fetishism is indeed an existing phenomenon in capitalism. The explanation I give here of commodity fetishism cannot do full justice to Marx. My aim is to supply a clear reconstruction that will be useful for testing the analogy with sexual objectification.

First, what is a fetish? A dictionary entry states: a fetish is "an inanimate ob- 
ject worshipped ... on account of its supposed inherent magical powers, or as being animated by a spirit." ${ }^{39}$ For Marx, capitalism turns commodities into fetishes. Commodities are useful objects or services that are bought and sold in market transactions. ${ }^{40}$ In capitalism such commodified objects or services are additionally fetishized: elevated to have inherent "magical" value. But sexual objectification does not elevate anything, one might say-rather it degrades women. So where is the analogy?

It has to do with how fetishism and how sexual objectification operate. Commodity fetishism specifies how objects acquire their fetish character-it specifies a mechanism. This mechanism, I argue, is analogous to sexual objectification. MacKinnon, as quoted in the introduction, talked about "the value of a commodity." Commodity fetishism is apparently about something that happens to this value. But what kind of value does she mean? Value as socially necessary labor time. To understand this, we need a small detour via three kinds of value that Marx distinguishes: use-value, exchange-value, and value as socially necessary labor-time. Note that all of these are substantially different from value in the moral sense.

First, use-value describes the "usefulness of a thing." ${ }^{41}$ Here is an example: a table with legs of the same length will be more useful than a table with legs of different length. It might, however, be that the second table took more time and skill to produce. This has no impact on its use-value: that "is independent from the labor required to appropriate its useful qualities." ${ }^{2}$

How do we trade useful commodities for one another? Via exchange-value: this "appears first of all in the quantitative relation, the proportion, in which use-values of one kind exchange for use-values of another kind." ${ }^{43}$ I can exchange the tables above with a pearl bracelet.

But how do we determine the ratio of exchange? It cannot be via use-value: following Marx, it is impossible to compare the usefulness of tables with the usefulness of pearl bracelets - they are useful for very different things. ${ }^{44} \mathrm{We}$ might then suspect that exchange-value is fixed by the amount of labor that was invested in producing it-Marx calls this "concrete" labor. But that cannot be right either: if I produce a table, this will take at least twenty times longer than if a carpenter does so. But if my table and her table enter the market, my table will

Carver, citing the Oxford English Dictionary, in "Marx's Commodity Fetishism," 51.

Cohen, "The Labour Theory of Value and the Concept of Exploitation," 339.

Marx, Capital, 1:126.

Marx, Capital, 1:126.

Marx, Capital, 1:126.

Marx, Capital, 1:128. 
not suddenly be twenty times more expensive than hers. Exchange-value cannot reflect actual labor-time.

What is it then? Marx introduces value-the value MacKinnon speaks of in the quoted passage in the introduction. Value is determined by "socially necessary labour-time" and exchange-value is a representation of value. ${ }^{45}$ Socially necessary labor-time "is the labour-time required to produce any use-value under the conditions of production normal for a given society and with the average degree of skill and intensity of labour." ${ }^{36}$ This means that value does not orient itself on concrete labor that went into a product, but on an abstraction. "The amount of time actually spent producing it [is] ... strictly irrelevant to its value." ${ }^{37}$

But this also means, following Marx, that we come to think of value as inherent in the commodity itself: we observe that value cannot have come from concrete labor, so it must come from elsewhere. To us the only viable option, following Marx, seems to be that it comes from the commodity itself. ${ }^{48}$ This belief about inherent value in a commodity is false: a commodity does not have inherent value somehow within it, "so far no chemist has ever discovered" that. ${ }^{49}$ Rather the social relation of production-socially necessary labor-time-determines value. Looking back to MacKinnon's quote we now understand why she writes that "the value of a commodity ... is made to appear a quality of the object itself, inherent, independent of the social relation that created it." ${ }^{\text {"5 }}$

We might at this point wonder why commodity fetishism is so interesting to Marx: sure, it involves me holding a false belief-but only about the origin of value, not about the amount of the property's value itself. After all, the commodity really has value. I am just mistaken about where exactly this value came from: from social relations, not out of the commodity itself. But this mistake in character is bad in at least three ways: it prevents us from knowing something we ought to know (the epistemic way), it enslaves producers (the political way), and it makes us treat others as objects (the moral way). As we will see, sexual objectification shares exactly these three problems with commodity fetishism.

Marx, Capital, 1:129.

Marx, Capital, 1:129. This bit of Marx, the labor theory of value, is controversial: value might also be affected by things other than socially necessary labor time, such as the existence of a monopoly driving up exchange value, as noted by Cohen, “The Labour Theory," 350-51.

Cohen, “The Labour Theory”, 345, emphasis added.

Marx, Capital, 1:164.

Marx, Capital, 1:177. One difficulty for this conception is presented by commodities into which no labor went, e.g., virgin soil. Their value is determined by the social relations of exchange, but cannot be cashed out in terms of socially necessary labor time.

MacKinnon, Toward a Feminist Theory of the State, 123. 
But to draw conclusions for sexual objectification, we first need to make sure we are drawing our conclusions from the right comparison. Why commodity fetishism, why not, say, alienation? Alienation might also have moral, political, and epistemic aspects: alienated from others, we might cease to employ empathy and morally wrong our co-citizens; a society of alienated individuals might be an undesirable political order; and being alienated from others involves making the epistemic error that others are unlike me or that I have no influence on them. So alienation too has moral, political, and epistemic aspects; why not look to alienation for a model for sexual objectification?

For two reasons: first, alienation's moral, political, and epistemic aspects have no clear social function of upholding a social structure as is the case for sexual objectification. Instead, for alienation, the three aspects seem to be separate consequences of one phenomenon. When it is already unclear how these three aspects fit together there, looking at alienation will not help to answer this question of fit for sexual objectification. Second, alienation's moral, political, and epistemic aspects are very different from sexual objectification's parallel aspects: a moral disregard for humanity, a politically unjust hierarchy, and an epistemically flawed belief in inherent properties. Alienation, it seems, would not help us in constructing a combined account of sexual objectification.

Both reasons do not hold for commodity fetishism. First, commodity fetishism and sexual objectification are functionally alike: they are both playing a part in maintaining the status quo. I show this analogy in social structure in section 3 . Second, commodity fetishism also contains a false belief about inherent property (section 4), a moral disregard for humanity, and a politically unjust hierarchy (section 5). This means that sexual objectification and commodity fetishism are also alike regarding the content of moral, political, and epistemic aspects. ${ }^{51}$

\section{ANALOGY IN SOCIAL STRUCTURE}

Commodity fetishism and sexual objectification both occur within larger social structures of capitalism and patriarchy and have a status quo-maintaining role to play in them. This similarity in function means that, when comparing the two phenomena, we are comparing like with like.

Above I noted that sexual objectification (following MacKinnon) and com-

51 Further analogies might be drawn: between women's beauty and money as fetishized universal commodities, or between workers as creators of valuable commodities and women as sexual agents - the parts workers and women play in commodity production and sexual life is obscured. As these additional analogies are not essential to my main project of understanding the relation between three accounts of objectification, I will not pursue them further. 
modity fetishism are themselves structural: they are systems constituted by a multitude of single actions or beliefs, not merely a single action or belief. Here, I am interested in how both phenomena relate to larger social structures: capitalism and patriarchy. Sally Haslanger defines a social structure as "a network of social relations, some of which are to other people, some of which are to non-human animals, some to things." 52 A social relation, as Haslanger explicates in her writings on objectification, specifies an "extrinsic property of individuals" and "depends upon the organisation of social life." ${ }^{53}$ A social relation contrasts with natural relations or properties: to borrow one of Haslanger's examples, being a scapegoat is clearly social; it has nothing to do with the scapegoat's natural properties. We can add that for a network of such social relations to be a social structure it must exist over at least some time and within some social group. It then becomes a social structure of this particular social group. Exactly how long such relations must persist, how large the social group must at least or at most be, and how (in)frequently the social relations must be reaffirmed are questions for further debate. For my project a preliminary definition suffices. I will therefore say that a social structure is a persisting network of social relations within a social group.

Commodity fetishism supports class relations in capitalism; sexual objectification (as MacKinnon's political sense stresses most explicitly) reinforces patriarchal relations. ${ }^{54}$ Capitalism contains a network of social relations between a class of owners of the means of production and a class of workers laboring for this first class. ${ }^{55}$ These relations are typically relations of power inequality and domination. Commodity fetishism means, as I demonstrated, that the worth of a commodity is seen to be inherent in it, while it is actually produced by relations of production and exchange. This means that large parts of economic inequality will appear as arising out of the inherent property of a commodity. They will seem to be unrelated to human social relations and out of reach for humans to change: the commodity that is one's specific labor is inherently worth some limited amount, but not enough to afford another commodity, such as a house in a well-thought-of district. In this case commodity fetishism makes it so that one's social situation seems unalterable-the commodities that enable or prevent opportunities have a fixed inherent value. So commodity fetishism supports the pertaining capitalist social relations.

52 Haslanger, "What Is a (Social) Structural Explanation?" 128.

53 Haslanger, "On Being Objective and Being Objectified," 41.

54 This relation to patriarchy is also assumed in Nussbaum, "Objectification," 249-50, 271; and Langton, Sexual Solipsism, esp. 241-45.

55 Cohen, Karl Marx's Theory of History, chs. 3, 5. 
The same is true for sexual objectification within patriarchy. Patriarchy is a system of social relations such that "men constitute the dominant social group" and women the subordinate social group. ${ }^{56}$ Sexual objectification is one such relation: according to the moral and political senses specified in sections 1.1 and 1.2, men relate to women by treating them primarily as objects. According to the epistemic sense from section 1.3, this has to do with men's sexual desires. This degrading treatment reinforces the existence of men as the dominant social group, women as the subordinate social group, and according to the political sense, even eroticizes this order. In short, objectification reinforces patriarchy.

So both commodity fetishism and sexual objectification reinforce capitalist and patriarchal social structures. This gives us a starting point for a further analogy: the two phenomena work similarly in our social world. Both involve agents forming false beliefs about inherent properties of some $\mathrm{x}$ (section 4 ). This mechanism is so successful because it generates additional evidence for the formed beliefs (section 5). So the two phenomena not only are alike in overall social function but also in how they achieve this function.

In this section I already employed all three senses of sexual objectification to make clear its relation to patriarchy. But how is it that each aspect of objectification exists in our social world? I argue that they form a network to mutually enforce one other-this is also true of commodity fetishism and its moral, political, and epistemic aspects.

\section{FALSE BELIEFS ABOUT INHERENT PROPERTIES}

\subsection{Commodity Fetishism and False Beliefs}

To see how, in both cases, false beliefs about the inherent properties of some object or person are formed, I first turn to commodity fetishism, then to sexual objectification. In commodity fetishism, one forms the belief that commodities have their value inherently when it is really endowed onto them by the social relations of production and exchange.

How exactly is this false belief generated? In a supermarket "it is impossible to know anything about the labor or the laborers [who congealed value in the lettuce].... You cannot, for example, figure out in the supermarket whether the lettuce has been produced by happy laborers, miserable laborers, slave laborers, wage laborers or some self-employed peasant." ${ }^{\text {57 }}$ This is so because capitalism features private production and public exchange, following Marx: commodities 
are "the products of the labour of private individuals who work independently of each other... The producers do not come into social contact until they exchange the products of their labour." 58 This means that producers only interact with one another to exchange products once these are finished commodities. As a carpenter I only approach a pearl-bracelet maker to exchange some tables for a bracelet once my tables exist as finished products. But from my finished table neither I nor the pearl-bracelet producer nor some other agent can tell whether I worked on it for eight days or eight months. Sure, I know how long I worked on that table-but I know that from doing the work, not from looking at the finished product. This means that capitalist private production and public exchange make information about actual labor time epistemically inaccessible on the market.

But what is the relation between ignorance about actual labor time and the fetishizing belief that value is inherent in commodities? Since we cannot exchange commodities by comparing actual labor time involved in production and exchange, something else-we infer-must determine their exchange-value. But as actual labor time-coming from outside to the commodity-is not available, the determining factor must instead - it seems to us - come from the commodity's inside. So we come to believe, as I showed in section 2, that commodities have inherent value that determines exchange-value.

Summing up, agents in capitalism form beliefs about the inherent value of a commodity because the finished product (e.g., in the supermarket) does not speak of the social relations that endow value onto the commodity. It is this epistemic mechanism to which we will find an analogous mechanism in the case of sexual objectification. Objectification's epistemic sense outlined above, to do with projection, will have a role to play here.

\subsection{Sexual Objectification and False Beliefs}

What is the false belief in the context of sexual objectification? Sexual desire produces a projective belief about the inherent object-like character of women, following in particular the epistemic sense of sexual objectification. Let us look in more detail at how this false-belief formation works-it will work differently than in commodity fetishism, but will produce the same result: a false belief about an inherent property.

Projective belief is produced from sexual desire. I take it that sexual desire can be described as a desire for sexual pleasure. And desires for $x$ are generally desires for $x$ to obtain — philosophers of mind therefore speak of desires having 
propositional content. ${ }^{59}$ So my desire for sexual pleasure is my desire that I be in a state of sexual pleasure. We can further distinguish intrinsic and instrumental desire. Sexual desires that women are beautiful objects or conform to other sexual fantasies might be instrumental desires: one desires their satisfaction instrumentally so that one experiences sexual pleasure. ${ }^{60}$ It is these instrumental sexual desires that are the subject of projection.

Desires typically dispose one to act so that $x$ obtains, following what philosophers of mind call action-based theories of desire: I have a desire for tea, so I am disposed to go and make myself a cup of tea. ${ }^{61}$ Some sexual desires are action-based desires: I desire to have sex with my partner, which makes me disposed to ask them whether they also want to have sex. But desires in sexual objectification are different. They are projective, generating a belief without any external evidence for this belief. Here, "belief [rather than action] is driven by desire." ${ }^{62}$

As an aside, we might wonder about the status of these desires: Is one born with them, or does one socially acquire them? The desire for tea is partly social: while we all need to drink, a taste for tea partly depends on what beverages one is used to in one's culture. In the case of sexual desire, we can ask the same question: Are men's sexual desires to objectify women natural, social, or a mix of both? I follow MacKinnon in holding that they are at least to a large extent social. ${ }^{63}$ In a non-patriarchal society, what we want sexually might be very different.

So both commodity fetishism and sexual objectification involve agents forming false beliefs about the inherent properties of commodities and women-this is the epistemic component they share and the reason why both phenomena are epistemically bad. In an alternative, socialist world, an epistemic ill of commodity fetishism would not exist: there, "an association of free men, working with the means of production held in common ... [has] full self-awareness as one single social labour force." ${ }^{64}$ In this socialist utopia all free people would know about the social character of commodity value, while in capitalism they do not.

This epistemic ill is mirrored in sexual objectification: women are falsely believed to be object-like. We can point to a further epistemic ill in this case: pro-

59 Schroeder, "Desire."

60 Whether the agents who hold such instrumental desires will be aware of their instrumental nature is a different matter. It might well be that the objectifying, originally instrumental desire has acquired the phenomenology of an intrinsic desire.

61 Schroeder, "Desire."

62 Langton, Sexual Solipsism, 244.

63 MacKinnon, Toward a Feminist Theory of the State, 131-32.

64 Marx, Capital, 1:171, emphasis added. 
jective belief violates the rules for direction of fit. "Belief is supposed to fit the world." ${ }^{\prime 5}$ But in sexual objectification, as I have described it, belief fits sexual desire. Commodity fetishism lacks this second epistemic ill—does this harm the analogy?

\subsection{Marx's Comparison: Fetishism in Religion}

Objectifying beliefs, we might worry, seem very different from fetishizing beliefs: projection in one case has nothing to do with inference from the organization of production and exchange in the other. This difference in belief formation makes a possible comparison between sexual objectification and commodity fetishism thin and uninteresting, one might claim.

But Marx compares commodity fetishism to religion: religion has its own fetishism. ${ }^{66}$ And religion contains projective beliefs just like sexual objectification-so the analogy with sexual objectification is not so far-fetched, at least not for Marx. He writes: in "the misty realm of religion ... the products of the human brain [i.e., gods] appear as autonomous figures endowed with a life of their own, which enter into relations both with each other and with the human race." ${ }^{\prime 7}$ In religion, following Marx, we create gods, they are "products of the human brain." This means they are generated without making use of external evidence. And these gods appear to us as "autonomous figures," precisely not as created by our own brains. We are unaware of their real origin in our own brain. So gods, following Marx, are projected. ${ }^{68}$ This means that religious fetishism contains projection just like sexual objectification does. But if religion and sexual objectification share projection, sexual objectification and religion lead one to form beliefs in closely analogous ways. And if religion, for Marx, is analogous to commodity fetishism, then sexual objectification can be too.

Again, I have not done enough to argue for the parallel between religion and commodity fetishism; this would go beyond the scope of this paper-I merely explained why Marx holds that they are parallel. If commodity fetishism and religion are analogous, as Marx thinks they are, then Marx's commodity fetish-

65 Langton, Sexual Solipsism, 266.

66 It would be more historically accurate to say that Marx applies the idea of religious fetishes (already in Hegel, Vorlesungen über die Philosophie der Weltgeschichte, 222) to commodities.

67 Marx, Capital, 1:165.

68 The story is surely more complicated: religion is fundamentally social and as such not every member of a religious group will create their gods using their own brain — most will take over the gods others have created. This further raises the question of whether the creators might not have created religion intentionally, e.g., in order to justify their own power, rather than unintentionally via projection. Marx's short discussion in Capital is ambiguous on this point (1:165). 
ism and sexual objectification can be analogous too. Even though they differ in how exactly they produce false beliefs in inherent properties, this is still their epistemic commonality.

But how exactly can these beliefs continue to exist? Following MacKinnon, sexual objectification works because "men ... [have the] power to force the world to be any way their mind can invent." ${ }^{69}$ In section 5 I argue that men force the world so that it entails evidence for their objectifying beliefs-and in the case of commodity fetishism the world also comes to entail evidence for beliefs about inherent value. Here moral and political senses come into play and support the epistemic sense.

\section{EVIDENCE PRODUCTION}

\subsection{Commodity Fetishism and Evidence Production}

Evidence for the belief that commodities have inherent value and, correspondingly, for the belief that women are object-like, reinforces these beliefs. To explain how this evidence is formed I first turn to commodity fetishism, then to sexual objectification. ${ }^{70}$

What evidence is there for the belief that a commodity has inherent value? In a capitalist social world we observe others attaching inherent value to commodities. Here is a concrete example:

Real Estate Agent: Joan is an agent selling land. To determine the price of a piece of farmland she looks at the quality of the soil or the size of the property. This means she treats the land as if value came from itself: as if "ground rent grows out of the soil." ${ }^{11}$ She does not engage in minute research about the various possible human uses of this piece of land.

If I visit Joan during her work, I will find that she treats the land as inherently valuable: value is somehow in the "soil" itself. This treatment of commodities constitutes them as fetishes: they gain the social meaning of objects with inherent value once individuals treat them as such. But my observation of Real Estate Agent is evidence for my belief that value is inherent in commodities. Marx has his own example to demonstrate the same point: money. Money, following

69 MacKinnon, Toward a Feminist Theory of the State, 122.

70 It is worth noting that the evidence I will talk about might not only reinforce objectifying and fetishizing beliefs - it might also in some cases create them. The story I am telling here necessarily simplifies the existing social reality. The hope, however, is that it does so in illuminating ways.

71 Marx, Capital, 1:176. 
Marx, becomes the universal measure for value. Exchanging commodities for money is evidence that those commodities have inherent value, quantifiable in a particular currency. ${ }^{72}$

A political sense of commodity fetishism crystallizes itself: a network of social relations between consumers and commodities forms an elaborate system. This political aspect loops back to the epistemic aspect: evidence for the belief that commodities have inherent value is generated on the market where commodities are traded as if they had inherent value. Real Estate Agent showed what this manner might look like and how this evidence can be gathered.

But the political sense goes further, according to Marx: in commodity fetishism "production has mastery over man." ${ }^{73}$ Human creations "come to enslave and oppress their creators." 74 This-briefly sketched-is due to the false belief about inherent commodity value. This belief turns commodities into special things such that producers lead lives in which commodities play a central role: "they will [for example] be compelled ... to perceive given objects solely as 'things' that one can potentially make a profit on." 75 This hunt for profit enslaves men. Commodity fetishism therefore is not only an elaborate system, analogous to MacKinnon's analysis of sexual objectification. It is also politically objectionable because it oppresses social groups_-again analogous to MacKinnon's analysis.

Before I trace the moral aspect of commodity fetishism, let us first turn to evidence production for sexual objectification.

\subsection{Sexual Objectification and Evidence Production}

Epistemic sexual objectification produces evidence for its projective beliefs. This evidence can be found in instances of moral and political objectification. Men do not merely believe that women are things- "women are the things." ${ }^{76}$ What

72 Marx, Capital, 1:168-69.

73 Marx, Capital, 1:175.

74 Leopold, "Alienation."

75 Honneth, Reification, 22.

76 MacKinnon, Toward a Feminist Theory of the State, 120. But if women are things, why is treating them as such still bad? (Papadaki, "What Is Objectification?" 21, mentions this worry.) First, it is still politically bad: women should not be things. And it might be epistemically bad when it involves projection from sexual desires. Second, women are things in the sense that they socially count as things — think back to Haslanger's scapegoat. But this does not make them things in all senses: women remain human beings with certain (perhaps oppressed, but nevertheless existent) needs and abilities (e.g., nutrition, breathing, movement, action). Women do not become full objects, lacking any subjectivity. So objectification will remain morally wrong, even if to a lesser degree after successful previous objectification. 
does that mean? Women are things because they are treated as things-Nussbaum's favored moral sense captures this well. This treatment both constitutes and causes their existence as objects. I take this distinction between constitutive and causal social construction from Haslanger. ${ }^{77}$ For something to be constitutively constructed means that "in defining it we must make reference to social factors": marriage constitutes one as a wife. Something is causally constructed when "social factors play a causal role in bringing it into existence": that this wife speaks English is caused by how she learned the language. ${ }^{78}$ Applying this distinction to sexual objectification and commodity fetishism will help us see the relation between epistemic, moral, and political senses.

First, how are women treated as objects? In section 4 we saw that men hold projective beliefs about women - the epistemic sense. But projective beliefs can guide action. James Bond's belief that women are objects for his sexual pleasure might - when confronted with a woman — cause him to act accordingly and treat her as an object-the moral sense. But why does this constitute women's existence as objects? If Bond treats his Bond girls like he treats his cars (as objects), this means that the Bond girls come to socially count as car-like objects. Andrea Dworkin seems to have this constitutive relation in mind when she asserts that "those who can be used as if they are not fully human are no longer fully human in social terms; their humanity is hurt by being diminished."79 Usage as inferior, for Dworkin, is the very thing that means inferiority. This is analogous to Real Estate Agent in commodity fetishism: others treating women as objects constitutes them as objects just like others treating value as inherent in commodities constitutes inherent value. This so constituted social reality provides evidence for objectifying beliefs and so the moral sense of sexual objectification loops back to the epistemic sense.

For sexual objectification there is a second sense in which women are objects. (Moral) treatment of women as objects causes their existence as objects: as MacKinnon notes, "women have little choice but to become persons who then freely choose women's roles." 80 That women are objects becomes "empirically real." ${ }^{81}$ Constant treatment as an object might make me think that this treatment must be right about me: I must be object-like. But once I think that, I will start behaving accordingly. This means that men's objectifying treatment causes women to behave in object-like ways, e.g., paying immense attention to

77 Haslanger, "Ontology and Social Construction," 98, 103.

78 Haslanger, "Ontology and Social Construction."

79 Dworkin, "Against the Male Flood," 31.

80 MacKinnon, Toward a Feminist Theory of the State, 124.

81 MacKinnon, Toward a Feminist Theory of the State, 230. 
their outer appearance or presenting themselves as generally passive, quiet, or shy. Here we start to see how an elaborate system of sexual objectification can set up a gender hierarchy: (epistemic) projective beliefs lead to a particular (moral) treatment that (politically) causes women to become inferior. With this relation in mind, let us look back to commodity fetishism one last time.

\subsection{Three Aspects of Two Phenomena}

Is there causal social construction in commodity fetishism? Commodities (as objects) do not think or act at all-so for those this analogy falls down. ${ }^{82}$ But services are also commodities. Here the analogy can work: workers in capitalism might (due to the fetishization of the services they provide) center their lives around their work-this means that they alter their behavior and mindset. This centrality of work in our lives forms part of the political sense of commodity fetishism: the elaborate, enslaving system is not only produced by our relation to nonhuman commodities but also by relating to our services and our labor as a commodity.

Focusing on services as commodities, we can also discern a moral aspect of commodity fetishism, analogous to Nussbaum's account of sexual objectification: individuals are treated primarily as objects. ${ }^{83}$ How so? One consequence of commodity fetishism is that social relations between producers turn into relations between things. ${ }^{84}$ The exchange of my labor with someone else's labor (so that I acquire a pearl bracelet and they acquire tables) seems to be an exchange between bracelet and tables - not between human labor. This is so because commodity fetishism, as we saw, entails that value appears inherent in a commodity. But in this way commodities gain social significance-to such an extent that individuals think of themselves and others in the same way in which they think of commodities. Axel Honneth observes: "As soon as social agents begin to relate to each other primarily via the exchange of equivalent commodities, they will be compelled ... to regard each other solely as 'object' of a profitable transaction." 85 Commodity fetishism brings with it that we treat others as objects.

We have therefore traced political, moral, and epistemic aspects: commodity

82 Marx imagines what they would say if they could speak: "What does belong to us as objects ... is our value. Our own intercourse as commodities proves it" (Capital, 1:176). This is just as false as when women (due to causal social construction) said: "We are object-like. Our own behavior proves it."

83 Marx himself might have resisted the claim that such treatment is morally bad; on Marx and morality see, e.g., Wolff, "Karl Marx."

84 Marx, Capital, 1:165.

85 Honneth, Reification, 22. 
fetishism draws up an elaborate system of relations to commodities that enslaves especially workers; it makes us disregard others' humanity, viewing them only as exchangeable commodities or as mere means to acquire commodities; and it leads us to hold false beliefs about the inherent properties of commodities.

Note that causal (and to some extend constitutive) social construction for both sexual objectification and commodity fetishism only work if the treatment is frequent, or comes from a large or powerful group. If one little boy occasionally treated me as an object, I would laugh at him. This is different if the boy's treatment mirrors treatment by a large or powerful group. Men in patriarchy are such a group: "men have power." ${ }^{86}$ So MacKinnon was right: men's power has a role to play in sexual objectification-it produces a social reality that corresponds to objectifying beliefs. Here we see how epistemic and moral aspects bring about political aspects of sexual objectification. This is mirrored by commodity fetishism: if only one little boy occasionally fetishized his toy car, commodities would not become inherently valuable. It is different if the little boy's behavior was typical and mirrored by the behavior of real estate agents like Joan, adult car owners, and ordinary consumers. Only then does commodity fetishism become an elaborate and oppressive system, analogous to MacKinnon's political sense.

We began with MacKinnon's analogy that

like the value of a commodity, women's sexual desirability is fetishized: it is made to appear a quality of the object itself ... inherent, independent of the social relation that created it. ${ }^{87}$

Now we are in a position to fully understand this passage: we know what MacKinnon and Marx mean by value (section 2); we know why commodities are seen to have value attached to them inherently (section 2); we know that commodities' value is really due to social relations (section 2); we also know how object-like women are created by a social relation of men desiring women (section 5); and we know how this social relation is falsely portrayed as the inherent character of women (section 4). And section 3 showed that both phenomena play a status quo-supporting role.

Drawing together the important strings of our analogy, we can see how moral, political, and epistemic aspects of one phenomenon can mutually reinforce the other aspects. The epistemic aspect supported the moral aspect: agents act on their false beliefs about inherent properties and treat women and other workers as object- or commodity-like. The epistemic aspect also contributed to the political aspect: when women are believed to be inferior objects, they (consti-

86 MacKinnon, Feminism Unmodified, 119.

87 MacKinnon, Toward a Feminist Theory of the State, 123. 
tutively and causally) become inferior objects; and workers become enslaved by the fixation on commodities and services when belief in their inherent value is widespread. Moral and political aspects relate in that the first contributes to but also instantiates the second: individual cases of objectification are part of an elaborate political system; and individual transactions between agents on the market, where each agent is reduced to an instrument for acquiring commodities, are part of a system that downgrades workers and fetishizes commodities. Both moral and political aspects further function as evidence for the false beliefs the epistemic sense puts center stage: observing American Apparel, James Bond, Helmet Campaign, and Miller Lite, I might believe that women are inherently object-like; just like Real Estate Agent, a visit to the supermarket and using money might convince me of commodities' inherent value.

We can conclude that, when debating over which of the three outlined accounts of sexual objectification to favor, we must understand that all three hang together. They are neither rivals (as Papadaki had it) nor different projects (as Stock saw it). The various interrelating aspects of commodity fetishism provided a model for how to best think about this complicated picture. They also helped rectify the imbalance toward the moral account that debates on sexual objectification seem to have: I showed that the moral account on its own is incomplete as an account of sexual objectification. It cannot explain why objectification occurs and why it occurs so frequently. Paying attention to an interrelated system with moral, political, and epistemic components fares better.

We might further suspect that two analogous phenomena can also be overcome in analogous ways. Both depend on ignorance-about projection's role in objectification and about the market's role in making a commodity appear inherently valuable. Eradicate the ignorance and you eradicate objectification and fetishization. Surely this is easier said than done, but perhaps saying is a first step toward doing.

University of Cambridge
pmk41@cam.ac.uk

\section{REFERENCES}

Agence France-Presse. 'German Ministry under Fire over 'Sexist' Bike Safety Ad." The Guardian, March 24, 2019. https://www.theguardian.com/media/ 2019/mar/24/german-bike-safety-ad-featuring-model-in-bra-and-helmet -sexist. 
Anscombe, G.E. M. Intention. Oxford: Basil Blackwell, 1976.

Bartky, Sandra. Femininity and Domination: Studies in the Phenomenology of Oppression. New York: Routledge, 1990.

Bordo, Susan. Unbearable Weight: Feminism, Western Culture, and the Body. Oakland: University of California Press, 2004.

Cahill, Ann J. Overcoming Objectification: A Carnal Ethics. New York: Routledge, 2011.

Carver, Terrell. "Marx’s Commodity Fetishism.” Inquiry 18, no. 1 (1975): 39-63.

Chambers, Clare. "Feminism." In The Oxford Handbook of Political Ideologies, edited by Michael Freeden and Marc Stears, 562-82. Oxford: Oxford University Press, 2013.

Cohen, G. A. Karl Marx's Theory of History: A Defense. Oxford: Clarendon Press, 1978.

- "The Labor Theory of Value and the Concept of Exploitation." Philosophy and Public Affairs 8, no. 4 (Summer 1979): 338-60.

Dworkin, Andrea. "Against the Male Flood: Censorship, Pornography, and Equality." In Feminism and Pornography, edited by Drucilla Cornell, 19-38. Oxford: Oxford University Press, 2000.

Grosz, Elizabeth. Volatile Bodies: Toward a Corporeal Feminism. Bloomington, IN: Indiana University Press, 1994.

Harvey, David. A Companion to Marx's Capital: The Complete Edition. London: Verso, 2010.

Haslanger, Sally. “'But Mom, Crop-Tops Are Cute!' Social Knowledge, Social Structure and Ideology Critique.” Philosophical Issues 17 (2007): 70-91.

—. "On Being Objective and Being Objectified." In Resisting Reality: Social Construction and Social Critique, 35-82. Oxford: Oxford University Press, 2012.

__ "Ontology and Social Construction." Philosophical Topics 23, no. 2 (Fall 1995): 95-125.

_- "What Is a (Social) Structural Explanation?" Philosophical Studies 173, no. 1 (January 2016): 113-30.

Hegel, Georg W.F. Vorlesungen über die Philosophie der Weltgeschichte [Lectures on the Philosophy of History]. Hamburg: Felix Meiner Verlag, 1955.

Honneth, Axel. Reification: A New Look at an Old Idea. Oxford: Oxford University Press, 2008.

James, William. The Will to Believe. New York: Longmans, Green and Co., 1897. Kant, Immanuel. Lectures on Ethics. Translated by Louis Infield. New York: Harper and Row, 1963. 
Langton, Rae Helen. Sexual Solipsism: Philosophical Essays on Pornography and Objectification. Oxford: Oxford University Press, 2009.

Leopold, David. "Alienation." Stanford Encyclopedia of Philosophy (Fall 2018). https://plato.stanford.edu/archives/fall2018/entries/alienation.

Locke, John. An Essay Concerning Human Understanding. Vol. 1 of The Works of John Locke, 12th ed. London: Rivington, 1824. https://oll.libertyfund.org/ title/locke-the-works-vol-1-an-essay-concerning-human-understanding -part-1.

Mackie, J. L. Ethics: Inventing Right and Wrong. Harmondsworth: Penguin, 1990.

MacKinnon, Catharine A. Feminism Unmodified: Discourses on Life and Law. Cambridge, MA: Harvard University Press, 1987.

- Toward a Feminist Theory of the State. Cambridge, MA: Harvard University Press, 1989.

Marino, Patricia. "The Ethics of Sexual Objectification: Autonomy and Consent." Inquiry 51, no. 4 (2008): 345-64.

Marx, Karl. Capital. 2 vols. Translated by Ben Fowkes. London: Penguin Classics, 1990.

Nussbaum, Martha. "Objectification." Philosophy and Public Affairs 24, no. 4 (Autumn 1995): 249-91.

Papadaki, Lina. "Sexual Objectification: From Kant to Contemporary Feminism." Contemporary Political Theory 6 (2007): 330-48.

_. "What Is Objectification?" Journal of Moral Philosophy 7, no. 1 (January 2010): 16-36.

Saul, Jennifer M. "On Treating Things as People: Objectification, Pornography and the History of the Vibrator." Hypatia 21, no. 1 (Spring 2006): 45-61.

Schroeder, Tim. "Desire." Stanford Encyclopedia of Philosophy (Summer 2017). https://plato.stanford.edu/archives/sum2017/entries/desire.

Stock, Kathleen. "Sexual Objectification." Analysis 75, no. 2 (April 2015): 191-95.

—. "Sexual Objectification, Objectifying Images, and 'Mind-Insensitive Seeing-As.” In Evaluative Perception, edited by Anna Bergqvist and Robert Cowan, 295-310. Oxford: Oxford University Press, 2018.

Weiss, Gail. Body Images: Embodiment as Intercorporeality. London: Routledge, 1998.

Wolff, Jonathan. "Karl Marx." Stanford Encyclopedia of Philosophy (Winter 2017). https://plato.stanford.edu/archives/win2017/entries/marx.

Young, Iris Marion. On Female Body Experience: "Throwing Like a Girl" and Other Essays. Oxford: Oxford University Press, 2005. 